UDK 929Mozart:316.343-058.12

78Mozart:316.343-058.12

Aleš Nagode

Filozofska fakulteta Univerze v Ljubljani

Philosophical Faculty, University of Ljubljana

\title{
Vloga plemstva iz slovenskega dela avstrijskih dednih dežel v življenju in delu Wolfganga A. Mozarta
}

\section{The Nobility of the Slovene Part of Austrian Lands and its Role in the Life of W. A. Mozart}

Ključne besede: klasicizem, W. A. Mozart, aristokracija, Slovenija

IZVLEČEK

Avtor v prispevku orisuje vpliv, ki so ga imeli člani plemiških rodbin s slovenskega dela avstrijskih dednih dežel na življenje in delo W. A. Mozarta. Pri tem opazuje vlogo, ki jo je imela dejavna podpora pripadnikov tega družbenega sloja v Mozartovem uveljavljanju v evropski kulturni javnosti.
Key words: classicism, W. A. Mozart, aristocracy, Slovenia

\section{ABSTRACT}

Author observes the nobility of the Slovene part of Austrian lands and its role in the life of W. A. Mozart. He stresses the importance of the few key aristocratic benefactors in Mozart's rise to the European fame. 
Tematika, ki se ji nameravamo posvečati v sledečem članku, se bo zazdela dobremu poznavalcu slovenske kulturne zgodovine nekoliko nenavadna. Najprej zato, ker najprej pomislimo na recepcijo Mozartovega ustvarjanja na Slovenskem, ki je že dokaj dobro raziskana. Odmev njegovih oper v slovenskih gledališčih tega časa dobro poznamo iz temeljitih študij Jožeta Sivca. ${ }^{1}$ Simfonična in koncertantna dela so lahko pred občinstvom slovenskih dežel zaživela le v izvedbi ljubljanske Filharmonične družbe, ustanovljene nekaj let po skladateljevi smrti. Njeno delovanje je bilo v kratkem času deležno kar nekaj monografskih obdelav, nazadnje izpod peresa Primoža Kureta, ${ }^{2}$ v katerih lahko zlahka razberemo obseg in kontekst izvajanja Mozartovih del v Ljubljani. Končno lahko iz vedno popolnejših katalogov glasbenih zbirk s konca 18. in iz začetka 19. stoletja sklepamo tudi na stopnjo razširjenosti cerkveno-glasbenega opusa velikega mojstra, ki je - kot je bilo za ta čas značilno - le stežka prehajal regionalne meje znotraj avstrijskih dednih dežel. Velika praznina sicer zeva v našem poznavanju vloge Mozartove glasbe v domačem muziciranju, a ta zvrst se - nenazadnje zaradi zasebnega značaja in s tem povezanega pomanjkanja oprijemljivih virov - nasploh izmika znanstvenemu opazovanju.

Drugi razlog, zaradi katerega bi se slovenskemu bralcu zdelo ukvarjanje z izbrano tematiko nekoliko nenavadno, je splošni odnos do plemstva, kakršen se kaže v pretežnem delu dosedanje slovenske kulturno-zgodovinske literature. Tega je v veliki meri narekoval politični razvoj najprej avstrijske, nato pa jugoslovanske države v zadnjem dobrem stoletju in pol. Visoko plemstvo slovenskega dela dednih dežel je kar po vrsti postalo tarča političnih sil, ki so zmagovito določale politično usodo in vladajočo resnico na ozemlju slovenskih dežel. Najprej je bil to politični liberalizem, ki je v starem plemstvu videl predvsem okostenelo oporo habsburškega aboslutizma. Nato goreči nacionalizem let po 1. svetovni vojni, ki si je prizadeval iz slovenske kulture izgnati vse kar je spominjalo na preteklo, z nemško govorečim delom dednih dežel povezano kulturo in ki je iz slovenskih dežel pregnal velik del tega sloja ter ob tem brezbrižno spremljal propad dobršnega dela njegove premične kulturne dediščine. Delo je končala bojevita proletarska revolucionarnost s popolno gospodarsko in v nekaterih primerih celo fizično likvidacijo tega sloja, ropanjem preostale premične in uničevanjem nepremične kulturne dediščine. Končala je proces, v katerem so gradovi in plemiška kultura postali simbol socialnega in narodnostnega zatiranja ter ga s surovo učinkovitostjo svoje propagande vsadila globoko v zavest vsakega slovenskega državljana.

Pa vendar se že površnemu bralcu slovenske glasbene zgodovine vsiljuje vprašanje, kako to, da ima geografsko, politično in kulturno dokaj trdno povezan prostor avstrijskih dednih dežel, tudi glede vpliva na Mozartovo življenje in delo, tako različno zgodovino. Na eni strani imamo avstrijsko zgodovinopisje, katerega pogled je - vsaj glede druge polovice 18. st. - še danes usmerjen le na Dunaj, ki se je v tem času povzpel med evropske glasbene metropole, in nam kaže blišč "avstrijske" glasbene zgodovine, katerega kronski dragulj je delo treh velikanov dunajske klasike. Na drugi strani imamo slovensko glasbeno zgodovinopisje, ki se izčrpuje v vernem naštevanju vseh drobnih odbliskov prestolne slave v slovenskem delu avstrijskih dednih dežel in ob tem tarna o prislovičnem slovenskem "zamudništvu". Ob tem pa obe glasbeno-zgodovinopisni šoli spregledujeta dejstvo, da prostor med Salzburgom in Dunajem - v katerem se je odvijal dobršen del Mozartove kratke življenjske poti - kljub sorazmerno višji gospodarski razvitosti nikakor ni mogel tvoriti gospodarskega in kadrovskega zaledja, ki bi lahko vzdrževalo glasbeno življenje evropske glasbene metropole in omogočalo ustvarjalni razcvet genijev, kakršni so bili J. Haydn, W. A. Mozart in L. van Beethoven. Že površen pogled na ekonomsko plat biografij velike trojice pokaže, da je bil njihov dohodek tako ali drugače odvisen od tanke plasti aristokracije iz vseh

\footnotetext{
Sivec, Jože. Opera v stanovskem gledališču v Ljubljani od leta 1790 do 1961. Ljubljana: Slovenska matica, 1971.

Kuret, Primož. Ljubljanska filharmonična družba : 1794-1919: kronika ljubljanskega glasbenega življenja v stoletju meščanov in revolucij Ljubljana: Nova revija, 2006.
} 
pokrajin habsburške oblasti. Na njenem čelu je bila cesarska družina iz katere so nekaj stoletij zapored na prestol sedali strastni ljubitelji glasbe, celo skladatelji in odlični amaterski glasbeniki. Prav navdušenje vladajoče dinastije je ukvarjanje $\mathrm{z}$ glasbo povzdignilo v družabno konvencijo, še več, v modno obsedenost, zaradi katere so nekateri manj preudarni aristokrati celo zapravljali premoženja (npr. Haydnov prvi delodajalec grof Morzin.) Za glasbo navdušena aristokracija je bila tista, ki je s svojimi velikodušnimi honorarji vzdrževala glasbo srednjeevropske metropole in s svojim obiskom ali odsotnostjo pogosto odločala o uspehu ali neuspehu posameznega glasbenega dogodka in s tem tudi marsikaterega glasbenika. Ekonomsko in socialno zaledje Mozartovega uspeha na Dunaju je bilo torej veliko širše in je - kot bo vsaj delno poskušal pokazati pričujoči prispevek - zajemalo tudi slovenski del avstrijskih dednih dežel.

Dosedanji pregledi so se, pri opazovanju stikov slovenskega dela avstrijskih dednih dežel z Mozartovim življenjem in delom, omejevali na opazovanje posameznikov in korporacij, ki jih lahko uvrstimo v srednji, meščanski sloj. Med prvimi so predvsem ugledne osebnosti iz vrst novega, hitro vzpenjajočega se denarnega in uradniškega plemstva (npr. Zois), med drugimi pa Filharmonična družba. Popolnoma spregledan pa ostaja sloj visokega in starega deželnega plemstva, ki je zaradi svojega premoženja, družbenega ugleda in nenazadnje opravljanja vrste pomembnih posvetnih in cerkvenih služb imel bistveno večje možnosti vplivati na razvoj glasbene kulture. Te so bile v nekaterih primerih tolikšne, da so močno presegle lokalne razmere v slovenskem delu avstrijskih dednih dežel, ter so pomembno vplivale tudi na nekatere, za evropski glasbeni razvoj ključne osebnosti.

Mozart je že v otroštvu prišel v stik z osebnostmi, ki jih lahko umestimo v krog visokega plemstva, povezanega s slovenskim delom avstrijskih dednih dežel. Verjetno najpomembnejši med njimi je bil prav njegov vladar in prvi delodajalec, salzburški nadškof Sigismund Krištof grof Schrattenbach. Izhajal je iz pomembne plemiške rodbine, ki je imela posesti tudi v slovenskem delu Štajerske, v vzporedni veji pa se je razmahnila še na Moravskem. V Gradcu rojeni Sigismund Krištof je prišel v posebno tesen stik s slovensko govorečimi sodeželani v času šolanja na takrat sloviti latinski šoli v Rušah (vpisan leta 1687). Šola, ki jo je 1645 ustanovil tamkajšnji župnik Jurij Kozina, je bila do ustanovitve jezuitskega kolegija v Mariboru edini tovrstni zavod v tem delu Štajerske. Obiskovali so jo dijaki različnih socialnih slojev od cvetobera štajerskega visokega plemstva do preprostih kmečkih otrok. Šola je dosegala izredno visoko raven pedagoškega dela, ki ni bistveno zaostajala za ravnjo bolj znanih jezuitskih kolegijev. Kot zanimivost lahko omenimo, da sta bili del učnega načrta tako uprizarjanje gledališčih iger kot učenje slovenskega jezika. ${ }^{3}$ Kasnejši nadškof je študij nadaljeval v Salzburgu in v Rimu, opravljal nato nekaj pomembnih služb v okviru salzburškega kapitlja ter bil leta 1753 izvoljen za salzburškega nadškofa in deželnega kneza.

Odnos med nadškofom Schrattenbachom in družino Mozart je bil precej ambivalenten. Na eni strani lahko v družinski korespondenci mestoma zasledimo zlasti Leopoldovo užaljenost zaradi nadškofovega podcenjevanja domačih glasbenikov in favoriziranja Italijanov, ki je še zaostrena z značilno razsvetljensko nenaklonjenostjo do klera nasploh. Na drugi strani pa ne moremo prezreti dejstva, da je nadškof družini dopuščal veliko svobodo pri razvijanju in izkoriščanju Wolfgangovega talenta. Leopold Mozart je lahko več let popotoval s svojimi otroci po evropskih deželah, brez skrbi za svojo plačo ali delovno mesto. Tako ravnanje je bilo v tistem času redko in ga lahko dejansko razumemo kot podporo pri razvijanju in razkazovanju čudežnega daru, ki je bil dan deželi Salzburg. Vrednost te tihe nadškofove podpore je družina znala ceniti šele pod njegovim naslednikom, ki je na vprašanje odnosa do družine Mozart gledal s pogledom hladne poslovnosti.

3 Mlinarič, Jože in dr. (ur.). Ruška latinska šola. Ruše, 1995. 
V Salzburgu je družina Mozart prišla v stik še z vrsto drugih predstavnikov visokega plemstva, ki so prihajali iz slovenskega dela avstrijskih dednih dežel. Nekaj je bilo znancev in sorodnikov, ki jih je na knežji dvor pritegnil nadškof Schrattenbach, spet druge je v cerkveno prestolnico severnega dela slovenskih dežel pripeljal študij na salzburški univerzi ali možnost vzpona v cerkveni hierarhiji. Med njimi lahko tu omenimo le nekaj najzanimivejših. Wolfgangov soigralec pri njegovem prvem javnem nastopu v šolski drami Sigismundus Hungariae Rex, ki so jo izvedli 1. in 3.9.1761, je bil predstavnik stare in celo z legendami ovenčane kranjske plemiške rodbine Maksimiljan Jožef grof Lamberg, takrat magister filozofije in študent prava na salzburški univerzi. ${ }^{4}$ Pri izvedbi baleta Appolo et Les Muses, načrtovani za za pustni ponedeljek (10.2.) leta 1777, naj bi ob Mozartu sodelovala tudi neimenovana grofica Auersperg. ${ }^{5}$ V krog salzburških znancev, katerih usodo je družina Mozart v svojih pismih pozorno spremljala še daleč v osemdeseta leta, sodijo še Janez Gudaker grof Herberstein (opravljal različne službe na dvoru, mož Marije Avguste roj. grofice Schrattenbach, nadškofove nečakinje), ${ }^{6}$ Janez Anton grof Herberstein (lastnik zaseženih posesti v Šleziji, ki se je preselil v Salzburg), ${ }^{7}$ Jožef Franc Anton grof Auersperg (sin Henrika kneza Auerperga, vojvode Kočevskega. Lavantinski, nato krški in končno passauski škof, 1789 kardinal), ${ }^{8}$ Ferdinand grof Attems (dvorni kancler), ${ }^{9}$ Vincenc Jožef Franc Saleški grof Schrattenbach (lavantinski škof, od 1799 škof v Brnu; imel je pogoste družabne stike z družino Mozart), ${ }^{10}$ Seyfried grof Gallenberg (odstavljeni dekan iz Tittmoninga, ki se vrača domov z majhno pokojnino) ${ }^{11}$ in Janez Krstnik grof Thurn-Valsassina-Taxis (Leopoldov prvi delodajalec, nato ohranja družabne stike z družino Mozart). ${ }^{12}$

Ključno vlogo so imeli predstavniki visokega plemstva iz slovenskega dela avstrijskih dednih dežel tudi pri uspešni izvedbi velikih potovanj, na katera se je Leopold Mozart vedno znova podajal s svojimi otroki. Del poti na prvem večjem potovanju leta 1761 (Passau-Linz), je družino spremljal Ernest Janez Leopold grof Herberstein, tedaj še pomožni škof v Passau. ${ }^{13}$ Ker se je družina dlje časa zadržala v Linzu, je grof Herberstein odpotoval naprej na Dunaj in tam pripravil pot za senzacionalno predstavitev čudežnih otrok v salonih visokega plemstva. ${ }^{14}$ (Družina je ostala s kasnejšim linškim škofom v stiku tudi kasneje, kar lahko razberemo iz pogostih omemb v korespondenci. ${ }^{15}$ ) Teh koncertov so se udeleževali tudi predstavniki na Dunaju živečega visokega plemstva iz slovenskega dela avstrijskih dednih dežel (npr. Anton Franc baron Lamberg ${ }^{16}$ ), če jih niso pripravljali celo sami, kot npr. Franc grof Thurn-Valssasina ${ }^{17}$ ali Jožef Karel grof Windischgrätz. ${ }^{18}$

Plemiški podporniki iz vrst avstrijske aristokracije so bili družini v veliko pomoč tudi na velikem potovanju med leti 1763 in 1766. Med njimi je bil najpomembnejši Janez Karel Filip Cobenzl (1712-1770). Rojeni Ljubljančan je bil eden zadnjih predstavnikov družine, ki je v jožefinskem času pomembno vplivala na avstrijsko in evropsko politiko. Bil je sin Janeza Gašperja grofa Cobenzla, ki je imel na Notranjskem znatno posest (Jama, Logatec, Planina pri Rakeku), bil kranjski dežel-

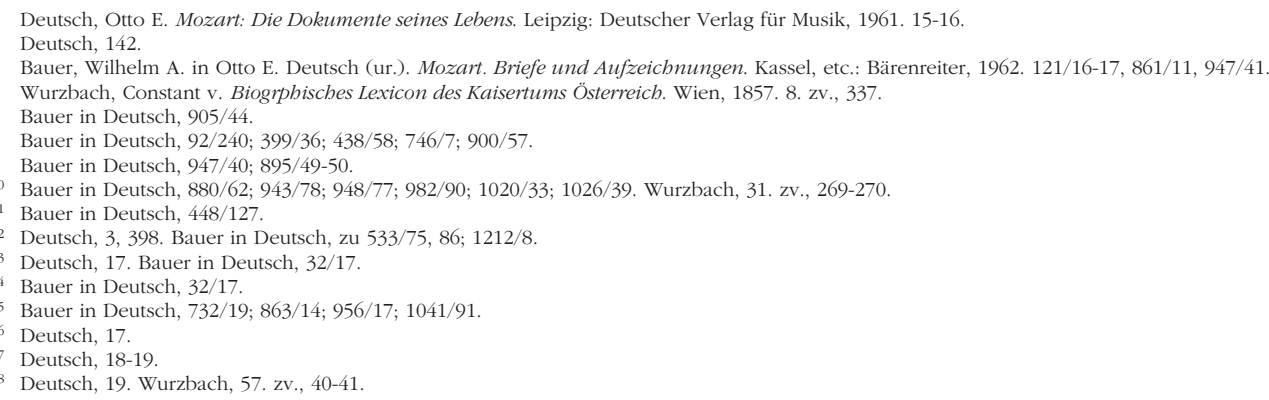


ni glavar, zraven pa - kar je za nas pomembneje - navdušen ljubiteljski glasbenik, ki je nekaj časa celo vodil ljubljansko Academijo philoharmonicorum (1740). Janez Karl Filip se je odlikoval v diplomatski službi in postal 1753 namestnik na Avstrijskem Nizozemskem (današnja Belgija). V zgodovino se je zapisal ne samo kot spreten politik in gospodarstvenik ("nizozemski Colbert"), temveč tudi kot razgledan razsvetljenski razumnik, ki je zbral sijajno knjižnico, bil predan podpornik umetnosti in ustanovitelj belgijske akademije znanosti. Politične zasluge so mu prinesle brezpogojno podporo cesarskega dvora, ki se ni kazala le v podeljenih časteh (postal je vitez reda zlatega runa), temveč tudi v tem, da mu je zaradi mecenstva finančno obubožanemu cesarica dvakrat odplačala dolgove in njegovi vdovi dodelila dostojno pokojnino. Ta velikodušni podpornik umetnosti je poskušal po svojih močeh utreti pot tudi Mozartovim, jih podpiral med obiskom v Bruslju in jim priskrbel priporočilna pisma za pariško aristokracijo (ki pa so bila - kot je v nekem pismu ugotovil L. Mozart - vredna manj kot poznanstvo in vpliv Friedricha M. v. Grimma). ${ }^{19}$

V Bruslju je družina navezala stik še z enim predstavnikom plemstva iz slovenskega dela avstrijskih dednih dežel. To je bil sorodnik družine Cobenzl, Rudolf grof Coronini-Cronberg. Pripadal je družini, ki je izhajala z Goriškega. Rojen je bil v Gorici (1731), študiral na Theresianumu na Dunaju in se nato mojstril v državniških znanostih v Bruslju. Očitno je moral biti dober znanec družine Mozart, saj se v korespondenci omenja kot "H: graf Coronini unser bester Freund, der alle Täg zu uns kommt “. ${ }^{20}$ Kmalu po obisku Mozartovih v Bruslju se vrnil v Gorico, kjer je postal 1767 pooblaščeni komisar goriških stanov in postopno napredoval do podpredsednika deželnega glavarstva. Pomemben je kot avtor vrste razprav o zgodovini Goriške. V svojem življenju se je tokrat nevede in posredno - dotaknil Mozartovega življenja in dela: v svojem goriškem domu je nekaj časa nudil zavetje velikemu libretistu Lorenzu da Ponte. ${ }^{21}$

Tudi v najbolj kritičnih trenutkih se je družina Mozart lahko oprla na pomoč svojih aristokratskih podpornikov. Najtežje obdobje mladosti Wolfganga A. Mozarta je bil brez dvoma čas drugega potovanja na Dunaj (1767), ko sta najprej Wolfgang, nato pa še sestra Maria Ana zbolela za kozami. Na paničnem begu z epidemijo prizadetega Dunaja so Mozartovim ob drugih zopet priskočili na pomoč Franz Anton grof Schrattenbach (brat salzburškega nadškofa in kasnejšega deželnega namestnik na Moravskem), njegova žena Maria Josepha (roj. Wrbna) in hči Maria Augusta grofica Herberstein (roj. Schrattenbach). ${ }^{22}$

Predstavniki visokega plemstva iz slovenskega dela avstrijskih dednih dežel pa so imeli pomembno vlogo tudi pri Mozartovi uveljavitvi v dunajskem glasbenem življenju po dokončnem prelomu s Salzburgom leta 1781. Kot ena ključnih osebnosti v tem procesu se kaže Janez Filip grof Cobenzl (nečak prej omenjenega Janeza Karla Filipa grofa Cobenzla), ki je bil rojen v Ljubljani leta 1741. Po študiju na univerzi v Salzburgu (ok. 1759-65), je svojo poklicno pot začel pod okriljem svojega strica v Bruslju. Že 1767 je postal uradnik v osrednjih dunajskih finančnih uradih, kjer je sodeloval pri uvajanju pomembnih finančnih reform. Očitno si je pridobil zaupanje, morda celo prijateljstvo cesarja Jožefa II., saj ga je leta 1777 spremljal na potovanje v Francijo. Odtlej je dobival vedno pomembnejše diplomatske naloge, postal vicekancler in prejel najvišja državna odlikovanja (veliki križ sv. Štefana, 1783; red zlatega runa, 1792). Umrl je brez potomcev leta 1810 na Dunaju, kot zadnji svojega rodu. ${ }^{23}$

Janez Filip Cobenzl je prišel v stik z družino Mozart že v času študija v Salzburgu. ${ }^{24}$ Najbolj odločilno pa je na Mozartovo življenjsko pot vplival v času njegovega osamosvajanja. Kot ugled-

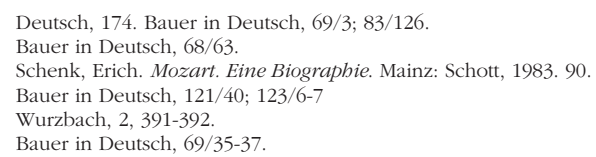


na osebnost dunajskega družabnega življenja in - kot lahko razberemo iz ohranjenih virov - zaupni cesarjev svetovalec je verjetno precej prispeval k Mozartovem bliskovitem vzponu v oboževanega virtuoza in opernega skladatelja. Razmerje med aristokratom in glasbenim genijem je bilo očitno zelo enakopravno in je precej presegalo okvire, ki so bili tedaj običajni v stikih med pripadniki aristokracije in ostalim prebivalstvom. V korespondenci se omenja cela vrsta družabnih stikov, od koncertov pri grofu, izletov na Cobenzlovo posestvo pri Dunaju, poučevanju njegove nečakinje, ipd. ${ }^{25}$ Mozart je znanstvo s Cobenzlom izkoriščal za čisto praktične usluge, kot so bile prenašanje pisem in pomoč pri načrtovani selitvi očeta in sestre na Dunaj. ${ }^{26}$ Stopnjo zaupanja kaže zaupna informacija o cesarjevem odnosu do papeževega obiska na Dunaju, ki jo je Mozart dobil od Cobenzla in jo nato posredoval svojemu očetu. ${ }^{27}$

Mozart je vzdrževal stike tudi z drugimi člani družine Cobenzl. Med njimi moramo omeniti Janeza Ludvika grofa Cobenzla, dolgoletnega poslanika na carskem dvoru v Rusiji in pomembnega soustvarjalca avstrijske zunanje politike napoleonskega časa. Njegovi ženi Therese (roj. de Montelabate) je Mozart posvetil izdajo treh sonat (Sonata za klavir v B, K. 333, Sonata za klavir v D, "Dürnitz", K. 284 in Sonata za klavir in violino v B, K. 454), ki so leta 1784 izšle kot njegov opus $7 .{ }^{28}$

K uveljavitvi Mozarta, kot ene od osrednjih osebnosti dunajskega glasbenega življenja, je močno prispevala tudi pozornost, ki jo je na Dunaju živeča aristokracija posvečala obiskovanju njegovih akademij. Seznam subskribentov za akademije spomladi leta 1784 je pravi kdo-je-kdo avstrijske aristokracije. Na njem najdemo tudi celo vrsto plemiških imen, katerih ožja domovina so bile tiste avstrijske dedne dežele, ki so bile v celoti ali delno poseljene s slovenskim prebivalstvom. Družino Auersperg zastopata knez Janez Adam in knez Karl s soprogo Marijo Josepho (roj. grofico Trautson-Falkenstein) ter grofje Karel, Viljem in Janez Ernest. Številčno močno je zastopana tudi družina grofov Herberstein (ljubljanski škof Karel Janez, Jožef, Jožef Franc Stanislav, Jožef Janez Nepomuk). Izmed predstavnikov nižjega plemstva ne smemo spregledati Jožefa Zoisa, brata bolj znanega Žige Zoisa. ${ }^{29}$

Verjetno najbolj očiten pa je bil delež kranjskega plemstva pri prvi dunajski izvedbi Mozartove opere Idomeneo, 13.3.1786. Pripravila jo je gledališka skupina, sestavljena iz plemiških ljubiteljev v gledališču kneza Auersperga, ki je stalo ob palači te družine v dunajskem predmestju. ${ }^{30}$ Izvedba je bila del obširnejše sezone, o kateri je javnosti poročala Taschenbuch für die Schaubühne auf das Jahr 1787. Spored sezone je prinašal nemške in italijanske opere in nemške in francoske komedije. ${ }^{31}$ Izvedbe Mozartovega Idomenea pa s slovenskim ozemljem ne povezuje le velikodušnost aristokratskega mecena kneza Auersperga. Med nastopajočimi v vlogi Idamanteja omenjeni Pulini je najverjetneje Ljubljančan Franc baron Pollini, sin ljubljanskega zdravnika Janeza Zlatoustega Pollinija in kasneje sloviti pianistični pedagog in skladatelj. Polinija je najverjetneje že leta 1783 Mozart kratek čas poučeval kompozicijo. ${ }^{32}$ Očitno pa njegov nastop pri izvedbi ni bil naključje, saj je Mozart prav zanj zložil celo dve vložni točki ter mu jih tudi posvetil. ${ }^{33}$

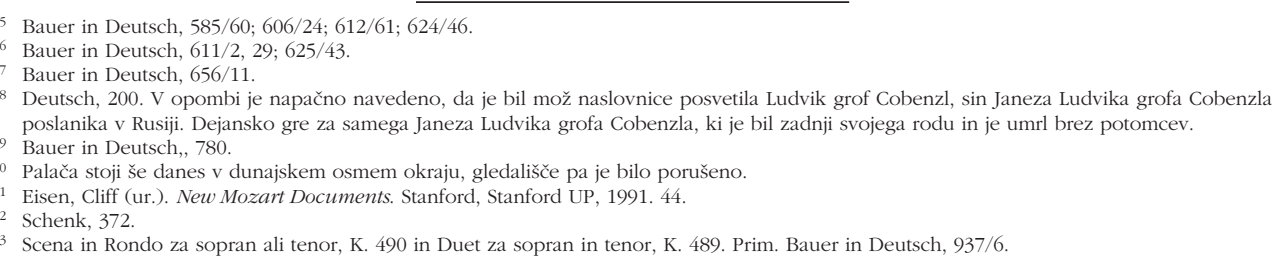


Ta kratek in nikakor izčrpen pregled vpliva plemiških posameznikov na življenje in delo Wolfganga A. Mozarta ne prinaša toliko novega v vedenje o biografskih okoliščinah ustvarjanja velikega skladatelja. Morda pojasnjuje sem in tja kakšno napačno navedbo, ali dopolnjuje že znana, a v virih in literaturi raztresena in spregledana dejstva. Pomembneje je, da nas predstavljena dejstva opozarjajo na to, da je bila usoda umetniških dragotin, v katerih lepoti lahko danes uživamo, nemalokrat odvisna od pomoči in dobre volje plemiških podpornikov, ki so se navduševali nad spretnostjo čudežnega otroka, ga znali nagrajevati, mu utirali pot v vrhove tedanje družbe, ga negovali v bolezni in podpirali na poti umetniške slave. Kaže nam, da je bil v tedanjih avstrijskih deželah - drugače kot v Parizu ali Londonu - za uspeh v kulturnem življenja odločilen tanek sloj med seboj tesno prepletenih plemiških družin, ki so s svojimi sredstvi omogočili čudež dunajske klasike. Mnogi od njih so v odnosu do glasbenega genija, ki so ga sprejemali kot sebi enakega, naredili velik korak $\mathrm{k}$ uresničitvi razsvetljenskih idealov.

Na drugi strani pa zbrana dejstva terjajo nov premislek o izhodiščih slovenskega glasbenega zgodovinopisja. Do sedaj začrtana omejenost na slovensko etnično ozemlje je mogoče nujna in v predmetu opazovanja utemeljena v zgodovini slovenske književnosti in jezika, ki je bil od začetkov slovenskega narodnega preporoda najbolj očiten znak slovenske samobitnosti. Zgodovina glasbene umetnosti na Slovenskem pa nam ob upoštevanju te omejitve riše nejasno in pomanjkljivo podobo. Opazovalcu se zdi, da vidi večje in manjše dele sestavljanice, ki pa združeni ne tvorijo zaključene celote, saj so le delček večje slike. Vzrok za to lahko vidimo v dejstvu, da omejitev na etnično ozemlje preddoloča literarno in glasbeno zgodovino na različna načina. Medtem ko je pri literarni zgodovini omejitev na posamezni jezik smiselna - saj je osnovno izrazilo te umetnosti - pomeni v glasbi nekakšno arbitrarno, zunajglasbeno omejitev. V glasbeni umetnosti, ki za nastajanje in recepcijo zahteva bistveno večja materialna sredstva, vodi - vsaj v slovenskem primeru - slepo enačenje socialno-kulturnega okvira z etničnim ozemljem do popolnega izkrivljanja zgodovinske podobe.

Slovensko ozemlje ni nikoli v svoji zgodovini predstavljalo take kulturne in politične celote, ki bi bila lahko okvir za razvoj celovite glasbene kulture. Knežji dvori, škofijski sedeži, industrijske metropole; vsi ti potrebni nosilci vrhunske glasbene kulture so v primeru slovenskega etničnega ozemlja ležali izven njega samega. Pa vendar je to ozemlje tja vedno znova pošiljalo denar in najboljše moči, ki so hranile kulturni cvet avstrijskih dednih dežel. Slovensko glasbeno zgodovinopisje bo moralo sprejeti dejstvo, da je bil slovenski etnični prostor vsaj do sredine 19. st. pač neločljiv sestavni del avstrijskih dednih dežel, katerih glasbena kultura je bila prav toliko slovenska kot je nemška. Droben prispevek k temu je tudi pričujoči sestavek, ki je želel pokazati, da se v guldnih, ki so jih aristokratski glasbeni ljubitelji potrošili za Mozartovo ustvarjanje, skriva tudi kri in znoj prebivalstva slovenskega dela avstrijskih dednih dežel.

\section{SUMMARY}

The higher nobility originating from the Slovene part of Austrian lands was till recently neglected by the Slovene historians. Author observes the nobility of the Slovene part of Austrian lands and its role in the life of W. A. Mozart. He stresses the importance of the few key aristocratic benefactors in Mozart's rise to the European fame. He observes certain points in his life (childhood in Salzburg, travels, breakthrough in Vienna) and the individual aristocrats connected with them. The personalities such as Salzburg archbishop Siegmund Christoph Count Schrattenbach, Johann Karl Phillip Count Cobenzl or Johann Phillip Count Cobenzl had 
very important role in Mozart's development and success with European and Viennese audience. The nobility of Slovene part of Austrian lands, living in Vienna, has significantly supported Mozart's activities, partly as subscribers to his musical academies and editions of his works, or as patrons and pupils. The extent and importance of its role call for new understanding of interweaveness between German-speaking and Slovene-speaking Austrian lands, and demands a new approach in research on Slovene cultural history. 